\title{
PENGARUH PEMBIAYAAN UMK IB TERHADAP PENGEMBANGAN USAHA MIKRO PADA BANK RIAU KEPRI CABANG PEMBANTU SYARIAH TEMBILAHAN
}

\author{
${ }^{1)}$ Sai 'in dan ${ }^{2)}$ Ferdinan \\ (Sekolah Tinggi Agama Islam Auliaurrasyidin Tembilahan) \\ ${ }^{1)}$ saiin@stai-tbh.ac.id ${ }^{2}$ ferdinan@stai-tbh.ac.id
}

\begin{abstract}
Abstrak
Penelitian ini berawal dari ada penawaran pembiayaan UMK $i B$ oleh Bank Riau Kepri Cabang Pembantu Syariah Tembilahan untuk usaha mikro dan kecil. Hal ini diharapkan dapat berpengaruh terhadap pengembangan usaha mikro. Target tumbuh sebesar $R p$ 1.816.796juta hanya terealisasi Rp1.663.355juta. Untuk segmen kredit mikro tahun 2013, target Kredit Pengusaha Kecil Rp1.149.190juta terealisasi Rp1.175.035juta sedangkan target Kredit Pengusaha Mikro 533.212juta terealisasi Rp161.377juta. Penelitian ini bertujuan untuk mengetahui pengaruh yang signifikan pembiayaan UMK $i B$ pada Bank Riau Kepri Cabang Pembantu Syariah Tembilahan. Dalam penelitian ini yang menjadi subjek penelitian adalah nasabah Bank Riau Kepri Syariah sedangkan objek penelitiannya adalah pengaruh pembiayaan pembiayaan UMK iB terhadap pengembangan usaha mikro. Jenis penelitian ini adalah penelitian kuantitatif karena hasil data yang didapat merupakan kumpulan dari pada angka-angka. Dengan menggunakan metode regresi sederhana karena dalam penelitian ini peneliti hanya menggunakan monosubjektif. Penelitian ini dilakukan selama 3 bulan. Hasil dari regresi menunjukkan nilai t hitung sebesar 3,165 sehingga t table 1,686< t hitung 3,165 dengan signifikansi 0,030 berada dibawah 0,05. Dengan demikian, dapat disimpulkan bahwa pembiayaan UMK iB pada Bank Riau Kepri Cabang Pembantu Syariah Tembilahan mempunyai pengaruh yang signifikan .
\end{abstract}

Kata Kunci: Pembiayaan UMK iB, Pengembangan Usaha Mikro. 


\section{A. Pendahuluan}

Islam sebagai agama yang universal dan komprehensif telah mengajarkan dan mengatur segala urusan manusia baik urusan duniawi maupun urusan akhirat, yang tidak hanya diterima bagi umat muslim saja akan tetapi, dapat juga diterima dikalangan non muslim. Setiap umat manusia dianjurkan untuk berusaha dan bekerja untuk memenuhi kebutuhan hidup. Hal ini dapat diketahui bahwa segala amal manusia tidak terlepas dari ketentuan-ketentuan hukum syariat yang terdapat dalam al-Qur'an dan alHadist maupun yang tidak terdapat pada keduanya, tetapi terdapat dari sumber-sumber lain yang diakui syari'at (Yahya \& fathurrahman, 1996).

Salah satu ketentuan yang tidak terlepas dari hukum syariat itu adalah mengenai rezeki yang dianungrahkan Allah pada manusia dari berbagai jalan dan cara dalam memenuhi kebutuhan hidup, baik diperoleh melalui jerih payah dan usaha yang sungguh-sungguh, atau dengan jalan yang tidak diduga dan disangka. Islam telah menetapkan agar individu dalam mencari nafkah guna memenuhi kebutuhan hidupnya dengan halal, begitu juga terhadap semua sarana untuk mendapatkan rezeki. Sesuai dengan firman Allah dalam surat al-Baqarah ayat 168. Artinya : "Hai sekalian manusia, makanlah yang halal lagi yang baik dari apa yang terdapat di bumi dan janganlah mengikuti langkah-langkah syaitan, karena syaitan itu adalah musuh yang nyata bagimu.” (QS al-Baqarah ayat 168)

Perkembangan ekonomi Islam identik dengan berkembangnya lembaga keuangan syariah. Salah satu filosofi dasar ajaran Islam dalam kegiatan ekonomi dan bisnis, yaitu larangan untuk berbuat curang dan dzalim. Semua transaksi yang dilakukan oleh seorang muslim haruslah berdasarkan prinsip rela sama rela (an taraddin minkum), dan tidak boleh ada pihak yang menzalimi atau dizalimi. 
Sebagai sebuah alternatif, Bank (lembaga keuangan) syariah telah memformulasikan sistem interaksi kerja yang dapat menghindari aspek-aspek negatif dari sistem kerja Bank konvensional, yaitu dengan menerapkan beberapa sistem, dimana harus diciptakan Bank (lembaga keuangan syariah) yang tidak bekerja atas dasar bunga melainkan atas sistem bagi hasil, antara lain yang dikenal dalam Bank (lembaga keuangan syariah) adalah pembiayaan.

Pembiayaan merupakan salah satu tugas pokok Bank, yaitu memberikan fasilitas penyediaan dana untuk memenuhi kebutuhan pihakpihak yang merupakan defisit unit. Menurut sifatnya pembiayaan dapat dibagi menjadi dua hal:

Pembiayaan produktif, yaitu pembiayaan yang ditujukan untuk memenuhi kebutuhan produksi dalam arti luas, yaitu untuk peningkatan usaha, baik usaha produksi, perdagangan, maupun investasi. Pembiayaan konsumtif, yaitu pembiayaan yang digunakan untuk memenuhi kebutuhan konsumsi, yang akan habis digunakan untuk memenuhi kebutuhan (Antonio. 2001: 160).

Dengan kondisi ini, kehadiran Bank Riau Kepri Syariah semakin melengkapi dan menjadi alternatif produk dan layanan perbankan yang dapat diberikan Bank Riau Kepri kepada masyarakat. Ditengah rentannya kondisi keuangan global, perbankan syariah di Indonesia mencatatkan kinerja yang sangat bagus, baik secara kualitas maupun kuantitas. Menurut statistik Bank Indonesia, perkembangan dan pertumbuhan perbankan syariah di Indonesia setiap tahunnya fantastis dan menggembirakan, tumbuh antara 40 sampai dengan 45 persen per tahun. Hal ini tercermin dari pertumbuhan aset, peningkatan pembiayaan, ekspansi pelayanan (jaringan kantor yang semakin meluas menjangkau 33 propinsi di Indonesia). Sebagian besar masyarakat Indonesia kini telah bersedia menerima prinsip syariah. Pemahaman akan keberadaan bank dengan prinsip syariah, sudah semakin familiar di masyarakat. Hal ini ditunjukan indikator perbankan yang sejalan dengan 
meningkatnya pasar perbankan syariah terhadap total perbankan nasional. Kondisi industri perbankan syariah semakin membaik di tahun 2013.

Pertumbuhan kredit mikro dan kecil di tahun 2013 menunjukkan hasil yang menggembirakan, dimana segmen kredit mikro dan kecil telah terealisasi sebesar 52,8\% menjadi Rp1.663.355juta di tahun 2013, dibandingkan posisi tahun 2012 yang hanya sebesar Rp1.364.697 juta. Sedangkan pada rencana bisnis Bank, segmen mikro dan kecil ditargetkan tumbuh sebesar Rp1.816.796 juta. Pertumbuhan kredit mikro dan kecil dari tahun 2010 sampai dengan tahun 2013. Dari tahun 2010 ke 2013, sektor pembiayaan pada Bank Riau Kepri Syariah terus mengalami pertumbuhan. Dari Rp. 223.275juta menjadi Rp. 619.026juta.

\section{Tabel 1.1}

\section{Target dan Realisasi Kredit}

\begin{tabular}{|c|l|c|c|c|c|}
\hline No & \multicolumn{1}{|c|}{ Jenis kredit } & $\begin{array}{c}\text { Realisasi } \\
\mathbf{2 0 1 2}\end{array}$ & $\begin{array}{c}\text { Target } \\
\mathbf{2 0 1 3}\end{array}$ & $\begin{array}{c}\text { Realisasi } \\
\mathbf{2 0 1 3}\end{array}$ & \% \\
\hline 1 & Kredit Pengusha Kecil & 912.250 & 1.149 .190 & 1.175 .035 & $102,25 \%$ \\
\hline 2 & Kredit Pengusaha makro & 183.675 & 533.212 & 161.378 & $30,27 \%$ \\
\hline 3 & $\begin{array}{l}\text { Kredit Ketahanan Pangan } \\
\text { Energi (KKP-E) }\end{array}$ & 23.197 & 33.801 & 39.594 & $117,14 \%$ \\
\hline 4 & Kredit Bank Riau Peduli & 1.045 & 1.557 & 343 & $22,03 \%$ \\
\hline 5 & Kredit KUMK SUP 005 & 4.034 & 4.215 & 2.626 & $62,30 \%$ \\
\hline 6 & Kredit Kepada BPR & 998 & 4.411 & 990 & $22,44 \%$ \\
\hline 7 & Kredit Agribisnis & 7.861 & 23.967 & 8.677 & $36,20 \%$ \\
\hline 8 & Kedai Bank Riau & 217.015 & 0 & 239.126 & $0,00 \%$ \\
\hline 9 & Kredit Koperasi/ LKM & 2.607 & 0 & 1.853 & $0,00 \%$ \\
\hline 10 & Kredit Usaha Rakyat & 12.014 & 66.443 & 33.732 & $50,77 \%$ \\
\hline & \multicolumn{1}{|r|}{ Total } & 1.364 .696 & 1.816 .796 & 1.663 .354 & $91,55 \%$ \\
\hline
\end{tabular}

Sumber: PT Bank Pembangunan Daerah Riau Kepri Laporan Tahun 2013

Dari total pembiayaan syariah di tahun 2013 tersebut, realisasi pembiayaan terbesar terdapat pada skema piutang, yakni sebesar Rp 603.512 juta yang sebelumnya sebesar Rp 412.259 juta pada tahun 2012. Produk berbasis murabahah (jual beli) menjadi penyumbang terbesar pada skema tersebut. Pertumbuhan pembiayaan PT. Bank Riau Kepri Unit Usaha syariah dari tahun 2010 sampai dengan tahun 2013. 
Hal-hal yang menjadi kendala dan permasalahan sektor pembiayaan antara lain sebagai berikut: Sektor Pembiayaan Produktif tidak mengalami pertumbuhan, Sedikitnya calon nasabah prospek yang layak menurut kriteria Bank untuk diberikan pembiayaan dengan akad bagi-hasil (Mudharabah dan Musyarakah). Sehingga pembiayaan lebih cenderung tumbuh dengan akad jual beli (Murabahah) dan Sebagian besar masyarakat masih mengusung gayahidup berpola konsumtif sehingga pembiayaan piutang tumbuh sangat signifikan dan tidak berimbang dengan pembiayaan produktif.

Dari tabel di atas dapat disimpulkan untuk pembiayaan produktif tidak mengalami peningkatan, karena pembiayaan mudharabah pada tahun 2012 Rp 745juta di tahun 2013 Rp 615Jjuta dan untuk pembiayaan musyarakah pada tahun 2012 Rp 6.917juta di tahun 2013 Rp 6.622juta, untuk kedua pembiayaan mudharabah dan musyarakah dari tahun 2012 ke tahun 2013 mengalami penurunan.

Berangkat dari fenomena di atas, penulis sangat tertarik untuk mendalami analisis Pembiayaan UMK iB di Bank Riau Kepri Cabang Pembantu Syariah Tembilahan dan pengaruhnya terhadap pengembangan usaha mikro. Di samping itu, penulis juga tertarik untuk melihat keterlibatan perbankan dalam pengembangan usaha mikro. Berdasarkan uraian di atas, peneliti dapat mengemukakan rumusan masalah yaitu sebagai berikut: Apakah pembiayaan UMK iB berpengaruh signifikan terhadap pengembangan usaha mikro pada Bank Riau Kepri Cabang Pembantu Syariah Tembilahan?

Adapun tujuan yang ingin dicapai oleh peneliti dalam penyusunan penelitian diantaranya: Untuk mengetahui apakah pembiayaan UMK berpengaruh signifikan terhadap pengembangan usaha mikro pada Bank Riau Kepri Cabang Pembantu Syariah Tembilahan. 


\section{B. Metodologi}

Penelitian ini dapat digolongkan sebagai penelitian lapangan (Field Researeh) dengan pendekatan kuantitatif yaitu suatu proses menemukan pengetahuan yang menggunakan data berupa angka sebagai alat untuk menentukan ketentuan yang mengenai apa yang ingin diketahui (S. Simargono, 2004).

Penelitian ini akan dilaksanakan pada Bank Riau Kepri Cabang Pembanru Syariah Tembilahan di JL. Jendral Sudirman - Pasar Baru Tembilahan Indragiri Hilir Telp. : 0768-325715/325716 Fax. : 0768-325717. Dalam penelitian ini yang menjadi subjek penelitian adalah nasabah Bank Riau Kepri Syariah sedangkan objek penelitiannya adalah pengaruh pembiayaan pembiayaan UMK iB terhadap pengembangan usaha mikro.

Populasi dalam penelitian ini seluruh nasabah pembiayaan UMK iB berjumlah 40 nasabah. Karena jumlah populasinya hanya 40 orang maka sekaligus dijadikan sampel dengan menggunakan teknik total sampling. Total sampling artinya menetapkan seluruh anggota populasi sebagai sampel (Feliatara, 2011).

Dalam penelitian ini, penulis menggunakan kuesioner dan dikembangkan model skala likert dengan alternatif penilaian 1sampai 5 kategori. Dengan menggunakan metode regresi sederhana karena dalam penelitian ini peneliti hanya menggunakan monosubjektif. 


\section{Hasil}

Tabel 2.2

Defenisi Konsep Operasional Penelitian

\begin{tabular}{|c|c|c|c|c|c|}
\hline No & Variabel & Defenisi variabel & Sup Variabel & Indikator & $\begin{array}{c}\text { No } \\
\text { item }\end{array}$ \\
\hline \multirow[t]{4}{*}{1} & \multirow[t]{4}{*}{$\begin{array}{l}\text { Produk } \\
\text { PembiayaaUMK } \\
\text { iB (Usaha Mikro } \\
\text { dan Kecil) } \\
\quad(\mathrm{X})\end{array}$} & \multirow[t]{4}{*}{$\begin{array}{l}\text { Pembiayaan UMK iB } \\
\text { (Usaha Mikro dan } \\
\text { Kecil) adalah } \\
\text { Disediakan untuk } \\
\text { membantu pengusaha } \\
\text { kecil baik secara } \\
\text { peroranggan maupun } \\
\text { kelompok dalam } \\
\text { memperoleh tambahan } \\
\text { modal kerja atau } \\
\text { investasi dangan prinsip } \\
\text { Murabahah. } \\
\text { Sumber: Dokumentasi } \\
\text { Bank Riau Kepri } \\
\text { Cabang Pembantu } \\
\text { Syariah, Tahun } 2014\end{array}$} & 1. Pelayanan & $\begin{array}{l}\text { 1. Pengajuan } \\
\text { pembiayaan } \\
\text { produk } \\
\text { Pembiayaan } \\
\text { UMK iB (Usaha } \\
\text { Mikro dan } \\
\text { Kecil) sangat } \\
\text { mudah dan tidak } \\
\text { berbelit-belit } \\
\text { 2. Pencairan dana } \\
\text { Pembiayaan } \\
\text { UMK iB (Usaha } \\
\text { Mikro dan } \\
\text { Kecil) } \\
\text { membutuhkan } \\
\text { waktu sangat } \\
\text { lama }\end{array}$ & 1 \\
\hline & & & $\begin{array}{l}\text {.Pengetahuan } \\
\text { produk }\end{array}$ & $\begin{array}{l}\text { 1. Nasabah telah } \\
\text { mengetahui } \\
\text { keguanaan } \\
\text { produk } \\
\text { Pembiayaan } \\
\text { UMK iB (Usaha } \\
\text { Mikro dan } \\
\text { Kecil) }\end{array}$ & 3 \\
\hline & & & 3. Akad & $\begin{array}{llr}\text { 1. } & \text { Akad } & \text { yang } \\
& \text { diterapkan Bank } \\
\text { Riau } & \text { Syariah } \\
\text { susah } & \text { untuk } \\
& \text { dipahami } & \end{array}$ & 4 \\
\hline & & & 1. Margin & 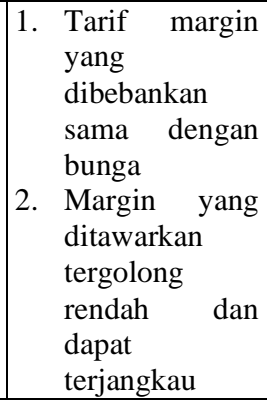 & 5 \\
\hline
\end{tabular}




\begin{tabular}{|c|c|c|c|c|c|c|}
\hline & & & 5. Jaminan & & $\begin{array}{l}\text { Jaminan yang } \\
\text { dititipkan } \\
\text { kepada Bank } \\
\text { Riau Syariah } \\
\text { dalam kondisi } \\
\text { baik dan aman } \\
\text { Jaminan yang } \\
\text { dikembalikan } \\
\text { kepada nasabah } \\
\text { dalam kondisi } \\
\text { baik }\end{array}$ & 7 \\
\hline & & & 6. Jangka waktu & & $\begin{array}{l}\text { 1.Jangka waktu } \\
\text { pijnaman yang } \\
\text { diberikan } \\
\text { tergolong lama } \\
\text { sehingga } \\
\text { meringankan } \\
\text { nasabah } \\
\text { Denda } \\
\text { keterlambatan } \\
\text { membayar } \\
\text { angsuran } \\
\text { bulanan } \\
\text { memberatkan } \\
\text { bagi nasabah }\end{array}$ & 9 \\
\hline 2 & $\begin{array}{l}\text { Pengembangan } \\
\text { usaha } \\
\text { (Y) }\end{array}$ & $\begin{array}{lr}\text { Menurut pendapat, } \\
\text { Allan } & \text { Affuah } \\
\text { Pengembangan usaha } \\
\text { merupakan sekumpulan } \\
\text { aktifitas yang dilakukan } \\
\text { untuk menciptakan } \\
\text { dengan cara } \\
\text { mengembangkan dan } \\
\text { mentransformasi } \\
\text { berbagai sunber daya } \\
\text { menjadi barang/ jasa } \\
\text { yang diinginkan } \\
\text { konsumen } \\
\text { Sumber: http://blog- } \\
\text { pinta.blogspot.com/201 } \\
\text { 3/06/kewirausahaan_49 } \\
\text { 53.html }\end{array}$ & 1.Pemanfaatan & & $\begin{array}{l}\text { Dari } \\
\text { pembiayaan } \\
\text { dapat } \\
\text { menambah } \\
\text { barang } \\
\text { dagangan } \\
\text { Pembiayaan } \\
\text { yang diperoleh } \\
\text { telah } \\
\text { diguanakan } \\
\text { untuk usaha } \\
\text { Dari } \\
\text { pembiayaan } \\
\text { usaha semakin } \\
\text { berkembang } \\
\text { Dari } \\
\text { pembiayaan } \\
\text { meningkatnya } \\
\text { produksi usaha }\end{array}$ & 4 \\
\hline & & & 2.Pendapatan & & $\begin{array}{l}\text { Pembiayaan } \\
\text { yang diperoleh } \\
\text { modal usaha } \\
\text { mengalami } \\
\text { peningkatan } \\
\text { Dana } \\
\text { pembiayaan } \\
\text { dapat membeli } \\
\text { peralatan dan } \\
\text { mempercepat } \\
\text { produksi } \\
\text { Omzet } \\
\text { pendapatan }\end{array}$ & 6 \\
\hline
\end{tabular}




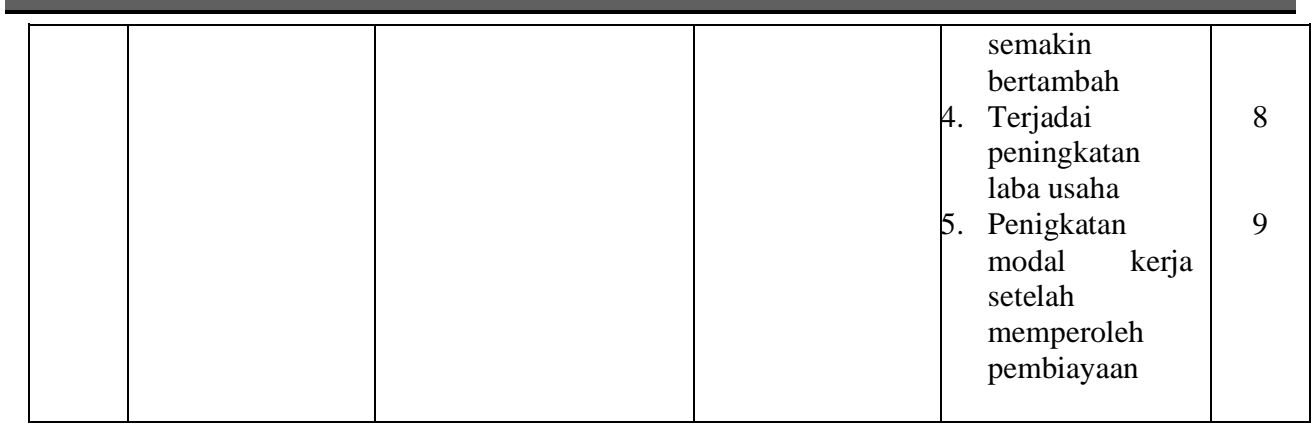

Sumber: Olahan Data Primer 2015

Data yang diperoleh dalam penelitian ini dikumpulkan dengan menyebarkan kuisioner kepada responden yaitu penduduk yang ada di daerah rengat. Kuisioner disebarkan dengan cara mengantar langsung kepada responden, setelah kuisioner selesai diisi oleh responden, peneliti mengambil kembali untuk selanjutnya ditabulasi dan diolah dengan menggunakan statistical package for social science (SPSS) versi 17.

Analisa data dilakukan terhadap 40 sampel responden yang telah memenuhi kriteria untuk dapat diolah lebih lanjut. Hasil pengolahan data statistik deskriptif ditunjukkan pada tabel berikut:

Tabel 2.3

Statistik Deskriptif

\begin{tabular}{|l|r|r|r|r|r|}
\hline & N & Minimum & Maximum & Mean & Std. Deviation \\
\hline Pembiayaan & 40 & 40 & 49 & 43,03 & 2,675 \\
Pengembangan usaha & 40 & 37 & 43 & 39,68 & 2,043 \\
Valid N (listwise) & 40 & & & & \\
\hline
\end{tabular}

Sumber: Pengolahan data SPSS

Berdasarkan tabel diatas terlihat bahwa nilai jawaban semua responden terhadap pembiayaan mempunyai nilai minimum sebesar 40 , nilai maksimum 49 dan nilai rata-rata 43,03 Pengembangan usaha mempunyai nilai minimum 37, nilai maksimum 43 dan nilai rata-rata 39,68.

\section{Uji Validitas}

Dalam pengujian yang dilakukan untuk mengetahui kualitas data, layak atau tidaknya sesuatu data untuk diangkat, maka peneliti menganalisa data dengan cara mengkorelasikan masing-masing skor item dengan skor 
total. Skor total adalah penjumlahan dari keseluruhan item. Item-item pernyataan yang berkorelasi signifikan dengan skor total manunjukkan itemitem tersebut mampu memberikan dukungan dalam menungkapkan apa yang ingin diungkap. Dalam uji validitas yang peneliti lakukan, penulis menggunakan korelasi Bivariate person (produk momen person) dan dilakukan dengan one shot method, yaitu metode yang dilakukan sekali pengukuran saja. Kuesioner dapat dikatakan valid jika nilai person correlation lebih besar dari nilai $\mathrm{r}$ tabel, $\mathrm{r}$ tabel dicari pada signifikansi 0,05 dengan uji 2 sisi dan jumlah data $(n)=40$, maka $r$ tabelnya adalah 0,320. Untuk variabel independen dan dependen, dari hasil uji validitas dapat disajikan sebagai berikut:

Tabel 2.4

Hasil Uji Validitas

\begin{tabular}{|c|c|c|c|c|}
\hline No & Variabel & Item & $\begin{array}{c}\text { Person } \\
\text { Correlation }\end{array}$ & $\begin{array}{c}\text { Keterang } \\
\text { an }\end{array}$ \\
\hline 1. & Pembiayaan $(\mathrm{X})$ & $\begin{array}{c}\text { Item1 } \\
\text { Item2 } \\
\text { Item3 } \\
\text { Item4 } \\
\text { Item5 } \\
\text { Item6 } \\
\text { Item7 } \\
\text { Item8 } \\
\text { Item9 } \\
\text { Item10 }\end{array}$ & $\begin{array}{l}0,494 \\
0,394 \\
0,456 \\
0,779 \\
0,676 \\
0,494 \\
0,456 \\
0,779 \\
0,560 \\
0,779\end{array}$ & $\begin{array}{l}\text { Valid } \\
\text { Valid } \\
\text { Valid } \\
\text { Valid } \\
\text { Valid } \\
\text { Valid } \\
\text { Valid } \\
\text { Valid } \\
\text { Valid } \\
\text { Valid }\end{array}$ \\
\hline 2. & Pengembangan Usaha (y) & $\begin{array}{l}\text { Item1 } \\
\text { Item2 } \\
\text { Item3 } \\
\text { Item4 } \\
\text { Item5 } \\
\text { Item6 } \\
\text { Item7 } \\
\text { Item8 } \\
\text { Item9 }\end{array}$ & $\begin{array}{l}0,337 \\
0,683 \\
0,337 \\
0,684 \\
0,489 \\
0,340 \\
0,332 \\
0,487 \\
0,361\end{array}$ & $\begin{array}{l}\text { Valid } \\
\text { Valid } \\
\text { Valid } \\
\text { Valid } \\
\text { Valid } \\
\text { Valid } \\
\text { Valid } \\
\text { Valid } \\
\text { Valid }\end{array}$ \\
\hline
\end{tabular}

Sumber: Pengolahan Data SPSS 
Dari tabel diatas dapat dijelaskan bahwa Pembiayaan dan pengembangan usaha dengan 19 item pertanyaan terdiri dari:

a. Pembiayaan dengan 10 item pertanyaan. Setelah dilakukan uji validitas menunjukkan nilai terendah sebesar 0,394, artinya semua item pertanyaan diatas 0,320 sehingga dapat dikatakan bahwa semua item pertanyaan memenuhi syarat untuk valid.

b. Pengembangan usaha dengan 9 item pertanyaan. Setelah dilakukan uji validitas menunjukkan nilai terendah sebesar 0,332, artinya semua item pertanyaan diatas 0,320 sehingga dapat dikatakan bahwa semua item pertanyaan memenuhi syarat untuk valid.

\section{Uji Realibilitas}

Uji reabilitas dilakukan dengan metode Cronbach Alpha menggunakan SPSS. Suatu konstruk atau variabel dikatakan reliabel jika memberikan nilai Cronbach's Alpha > 0,60. Pengukuran reabilitas dalam penelitian ini menggunakan metode one shot atau diukur sekali saja. Hasil uji reabilitas data dapat dilihat pada tabel berikut:

Tabel 2.4

Hasil Uji Realibilitas Data

\begin{tabular}{|l|c|c|c|}
\hline \multirow{2}{*}{ Variabel } & \multicolumn{2}{|c|}{ Hasil Reability ( Alpha) } & \multirow{2}{*}{ Keterangan } \\
\cline { 2 - 3 } & Kriteria & Cronbach's alpha & \\
\hline $\begin{array}{l}\text { Variabel Independen: } \\
\text { Pembiayaan }\end{array}$ & 0,60 & 0,746 & Reliabel \\
\hline $\begin{array}{l}\text { Variabel Dependen } \\
\text { Pengembangan Usaha }\end{array}$ & 0,60 & 0,681 & Reliabel \\
\hline
\end{tabular}

Sumber: pengolahan data SPSS

Dari tabel hasil pengujian reliabilitas yang disajikan pada tabel 4.4 menunjukkan tidak ada koefisien Cronbach Alpha yang kurang dari 0,60 sehingga instrument tersebut reliabel untuk digunakan. 


\section{Uji Normalitas}

Pengujian normalitas dapat digunakan dengan menggunakan one sample kolmogorov smirnov test dengan melihat signifikan 5\%. Dasar pengambilan keputusan dari uji normalitas ini adalah melihat probability asymp. Sig (2-tailed), jika probabilitas > 0,05 maka data mempunyai distribusi normal dan sebaliknya jika $<0,05$ maka data mempunyai distribusi yang tidak normal. Uji normalitas data dapat dilihat pada tabel berikut ini:

Tabel 2.5

\section{Hasil Uji Normalitas}

\begin{tabular}{|l|l|l|l|l|}
\hline Variabel & Nilai K-S-Z & Sig. (2-tailed) & Kriteria & Kesimpulan \\
\hline $\begin{array}{c}\text { Variabel independen: } \\
\text { Pembiayaan }\end{array}$ & 0,1418 & 0,036 & 0,05 & Normal \\
$\begin{array}{c}\text { Variabel dependen: } \\
\text { Pengembangan } \\
\text { Usaha }\end{array}$ & 0,1135 & 0,152 & 0,05 & Normal \\
\hline
\end{tabular}

Sumber: Pengolahan Data SPSS

Dari tabel diatas menunjukkan nilai K-S-Z untuk Pembiayaan sebesar 0,1418 dengan signifikansi 0,036, nilai K-S-Z untuk Pegembangan Usaha sebesar 0,1135 dengan signifikansi 0,152.

Apabila dibandingkan dengan nilai $\alpha=0,05$, maka semua nilai $\mathrm{K}-\mathrm{S}-\mathrm{Z}$ tersebut diatas 0,05 , jadi dapat disimpulakn bahwa variable pembiayaan dan pengembangan usaha secara statistik telah terdistribusikan secara normal dan layak digunakan sebagai data penelitian.

\section{Uji Asumsi klasik}

\section{a. Uji Multikolinearitas}

Uji multikolinearitas pada penelitian ini dilakukan dengan mengamati besaran varian inflation factor (VIF) dan tolerance. Besaran VIF dan tolerance pada penelitian ini sebagai berikut:

\section{Tabel 2.6}

Nilai VIF dan Tolerance

\begin{tabular}{|l|l|l|l|}
\hline Variabel & Tolerance & VIF & Keterangan \\
\hline Pembiayaan & 0,528 & 1,472 & Bebas Multikol \\
\hline
\end{tabular}


Sumber: Data Olahan SPSS

Dari diatas menunjukkan variabel pembiayaan mempunyai nilai tolerance sebesar 0,528 sedangkan nilai VIF sebesar 1,472.

Dari variabel independen tidak ada nilai VIF diatas 5, maka dapat disimpulkan tidak terdapat gangguan multikolinearitas pada penelitian ini sehingga penelitian ini bebas dan layak digunakan.

\section{b. Uji Heterokedastisitas}

Pengujian ini dilakukan dengan mengamati grafik scatterplot yaitu dengan melihat ada tidaknya pola yang terdapat pada grafik scatterplot. Hasil Uji heteroskedastisitas dapat dilihat pada gambar dibawah ini:

\section{Gambar 2.1}

\section{Scatterplot Heteroskedastisitas}

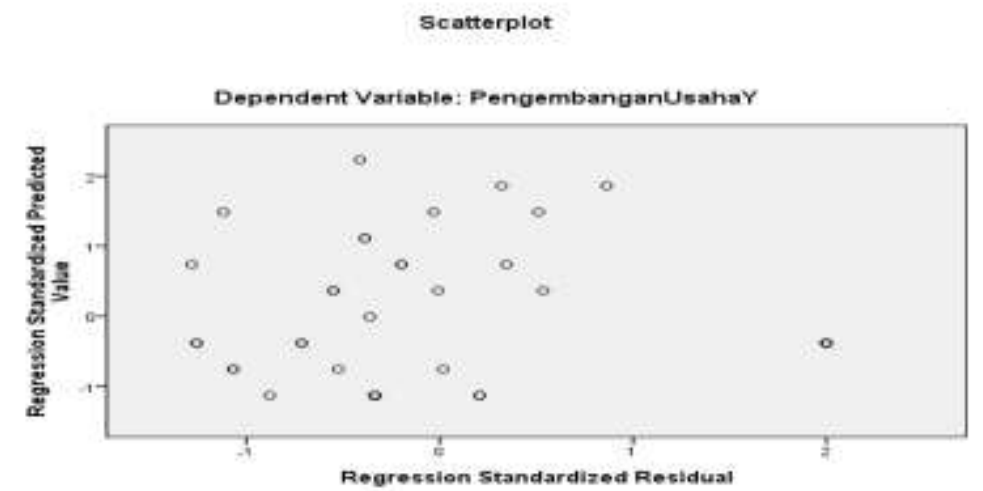

Dari gambar diatas dapat dilihat bahwa terjadi penyebaran titik dan tidak membentuk suatu pola.Hal ini dapat diindikasikan bahwa model tidak memiliki gejala heteroskedastisitas.

\section{Pembahasan}

Hipotesis pada penelitian ini menggunakan analisis regresi linear sederhana dengan bantuan software SPSS versi 17 dimana motode ini menganalisis variabel independen secara keseluruhan tanpa memilih variabel 
yang nantinya dijadikan satu kelompok dalam persamaan regresi atau semua variabel dimasukkan untuk mencari pengaruh antara variabel independen dan variabel dependen melalui regresi berganda. Hasil regresi berganda dapat dilihat pada tabel dibawah ini:

Tabel 2.7

\section{Hasil Uji Regresi Linear Sederhana}

\begin{tabular}{|c|c|c|c|c|c|c|c|}
\hline \multirow[b]{2}{*}{ Model } & \multicolumn{2}{|c|}{$\begin{array}{c}\text { Unstandardized } \\
\text { Coefficients }\end{array}$} & \multirow{2}{*}{$\begin{array}{c}\begin{array}{c}\text { Standardized } \\
\text { Coefficients }\end{array} \\
\text { Beta }\end{array}$} & \multirow[b]{2}{*}{$\mathrm{T}$} & \multirow[b]{2}{*}{ Sig. } & \multicolumn{2}{|c|}{ Collinearity Statistics } \\
\hline & B & Std. Error & & & & Tolerance & VIF \\
\hline $1 \quad$ (Constant) & 24,665 & 4,752 & & 4,191 & 0,010 & & \\
\hline PembiayaanX & 0,349 & 0,110 & 0,457 & 3,165 & 0,030 & 528 & 1,472 \\
\hline
\end{tabular}

a. Dependent Variable:

PengembanganUsahaY

Persamaan regresi adalah sebagai berikut:

$\mathbf{Y}=\mathbf{a}+\mathbf{b X}+\mathbf{e}$

$\mathrm{Y}($ Pengembangan usaha $)=24,665+0,349 \mathrm{X}+\mathrm{e}$

Berikut adalah penjelasan dari persamaan regresi berganda yang terbentuk:

a. Konstanta sebesar 24,665 menyatakan, bahwa jika variabel independen tetap maka variabel dependen adalah sebesar 24,665.

b. Nilai koefisien $b$ adalah 0,349 berarti bahwa apabila pembiayaan mengalami kenaikan satu poin sedangkan variabel indenpen lainnya tetap maka variabel dependen (Y) akan mengalami kenaikan sebesar 0,349.

Untuk melakukan pengujian terhadap pengaruh pembiayaan terhadap pengembangan usaha digunakan pengujian dengan uji t. Pengujian tersebut dilakukan dengan dua arah (2 tailed) dengan tingkat keyakinan 95\% dan dilakukan uji tingkat signifikan pengaruh hubungan variabel independen dengan variabel dependen. Tingkat signifikannya ditentukan sebesar 5\% dan degree of fredom $=\mathrm{n}-\mathrm{k}-1=40-1-1=38$. Didapat hasil $\mathrm{t}$ tabel sebesar 1,686. 
Kriteria pengujian yang digunakan adalah:

Jika t hitung > t tabel (n-k-1) maka Ho ditolak

Jika thitung < t tabel (n-k-1) maka Ho diterima

Selain itu uji t tersebut dapat pula dilihat dari besarnya probabilitas value ( $p$ value) dibandingkan dengan 0,0 (taraf signifikan $\alpha=5 \%$ ). Adapun kriteria pengujian yang digunakan adalah:

Jika $p$ value $<0,05$ maka Ho ditolak

Jika $p$ value $>0,05$ maka Ho terima

Adapun hasil dari uji tersebut sebagai berikut:

Ho: Pembiayaan UMK iB (Usaha Mikro dan Kecil) berpengaruh positif terhadap pengembangan usaha mikro dan kecil.

Tabel 2.8

Hasil Hitung Uji t

\begin{tabular}{|c|c|c|c|c|c|c|c|}
\hline \multirow[b]{2}{*}{ Model } & \multicolumn{2}{|c|}{$\begin{array}{l}\text { Unstandardized } \\
\text { Coefficients }\end{array}$} & $\begin{array}{l}\text { Standardized } \\
\text { Coefficients }\end{array}$ & \multirow[b]{2}{*}{$\mathrm{T}$} & \multirow[b]{2}{*}{ Sig. } & \multicolumn{2}{|c|}{ Collinearity Statistics } \\
\hline & B & Std. Error & Beta & & & Tolerance & VIF \\
\hline 1 (Constant) & 24,665 & 4,752 & & 4,191 & 0,010 & & \\
\hline PembiayaanX & 0,349 & 0,110 & .457 & 3,165 & 0,030 & 528 & 1,472 \\
\hline
\end{tabular}

a. Dependent Variable:

PengembanganUsahaY

Hasil dari regresi menunjukkan nilai t hitung sebesar 3,165 sehingga $\mathrm{t}$ table 1,686 < t hitung 3,165 dengan signifikansi 0,030 berada dibawah 0,05. Hasil ini menunjukkan bahwa pembiayaan secara signifikan berpengaruh terhadap pengembangan usaha.

\section{E. Kesimpulan}

Kesimpulan penelitian berkaitan dengan hasil analisis. Setelah diolah menggunakan program SPSS (statistical product and service solution) dengan menggunakan regresi linear sederhana diperoleh terdapat pengaruh yang signifikan antara produkp pembiayaan UMK iB dengan pengembangan usaha mikro pada Bank Riau Kepri Cabang Pembantu Syariah Tembilahan. 
Hal ini ditunjukkan dengan Hasil dari regresi menunjukkan nilai t hitung sebesar 3,165 sehingga t tabel 1,686 < t hitung 3,165 dengan signifikansi 0,030 berada dibawah 0,05 . Hasil ini menunjukkan bahwa hipotesis yang menyatakan pembiayaan berpengaruh terhadap pengembangan usaha dapat diterima. Dengan hasil bahwa pembiayaan secara signifikan berpengaruh terhadap pengembangan usaha

\section{Referensi}

A. Karim, Adiwarman, (2008), Bank Islam: Analisis Fiqh dan Keuangan, Jakarta: IIIT Indonesia, Edisi.I, Cet. Ke-I.

A. Mas'adi, Ghufron, (2002) Fiqh Muamallah Konstekstual, Jakarta: Raja Grafindo Persada, Cet. Ke-I.

Andi, M. kwartino, (2007) Analisis usaha Kecil dan Menengah. Yogyakarta: CV. Andi Offset.

Anonimous, (1993), Pedoman Pengelolaan Bank Syari'ah, Jakarta: LPPBS.

Antonio, Muhammad Syafi'i dan Tim Tazkia, (2010), Bisnis dan Kewirausahaan, Jakarta: Tazkia Publishing.

Antonio, Muhammad Syafi'i, (2001), Bank Syariah, Jakarta: Gema Insani, Cet. Ke-1.

Arikunto, Suharsimi, (2006), Prosedur Penelitian Suatu Pendekatan Praktik, Jakarta: PT. Rineka Cipta, Edisi Revisi IV.

Ascarya, (2007), Akad \& Produk Bank Syariah, Jakarta: PT. Raja Grafindo Persada, Cet. Ke-1, Edisi. I.

Ashari, Purbayu Budi Santoso, (2005), Analisis statistic dengan Microsoft exel dan SPSS, Yogyakarta: BPFE.

Departemen Agama RI, (2010), al-Qur'an dan Terjemahannya, Bandung: SIGMA PUBLISHING, Cet. Ke-1. 
Dokumentasi Bank Riau Kepri Cabang Pembantu Syariah Tembilahan, Tahun (2014).

Felitatra, dkk, (2011), Metodologi Penelitian Persiapan Bagi Peneliti Pemula, Pekanbaru: Faperika Press.

Ghozali, Imam, (2005), Analisis Multivariat dengan Program SPSS, Semarang: Penerbit UNDIP, 2005, Edisi ke-3.

Hartono, (2010), SPSS 16.0 Analisis Data Statistik dan Penelitian, Pekanbaru: Pustaka Pelajar dan Zanava.

Kasmir, (2007), Bank dan Lembaga Keuangan Lainnya, Jakarta: PT. Raja Granfindo Persada, Edisi. 6.

Laporan Tahunan PT Bank Pembangunan Daerah Riau Kepri Tahun 2013

Ramos, Mahendra, dkk, (2007), Aplikasi Program SPSS Dalam Analisis Data Penelitian, Pekanbaru: UIN Suska Press.

S. Simargono, (2004), Metodologi Penelitian Pendidikan, Jakarta: Reneka Cipta, Cet. ke 4.

Santoso, Singgih, (2010), Mandiri Belajar SPSS, Jakarta: Media Kom.

Sembiring, Sentosa, (2008), Hukum Dagang, Bandung: PT. Citra Aditiya Bakti, Cet. III.

Singarimbun, M, dan Effendi, (1989), Metode Penelitian Survai. Jakarta: Pustaka LP3ES Indonesia.

Sulaiman, Wahid, (2004), Analisis-Analisis Regresi menggunakan SPSS, Yogyakarta: CV. Andi Offset.

Tambunan, Tulus, (2012), Usaha Mikro Kecil Dan Menengah di Indonesia: Isu-isu Penting, Jakarta: LP3ES, 2012.

Yahya, Mukhtar dan fathurrahman, (1996) Dasar-Dasar Pembinaan Hukum Fiqh islam, Bandung: PT. Al-Ma'arif, Cet. Ke-1.

Yusuf, Ayus Ahmad dan Abdul Aziz, (2009), Manajemen operasional Bank Syariah, Cirebon: STAIN Press. 